Paedagogia Christiana

2/28 (20I I) - ISSN 1505-6872

Agnieszka Sojka*

Kraków

\title{
Obraz przyrody w pieśni religijnej
}

Świat współczesny wraz z procesami zurbanizowania i postępującymi w zaskakująco szybkim tempie zmianami w każdej sferze życia naznaczony jest globalnymi problemami ekologicznymi, wśród których istotnym zagadnieniem stają się tradycje folklorystyczne oraz związane z nimi obrzędy i wierzenia. Zjawisko wzrastającej wciąż liczby zachorowań na tak zwane choroby cywilizacyjne, wśród których nowotwory, cukrzyca, otyłość oraz choroby serca zbierają obfity plon w naszej codzienności, domaga się edukacji ekologicznej świadomie prowadzonej od początku procesu wychowania młodych pokoleń. Obejmować powinna ona nie tylko problematykę zawartą w treściach edukacji zdrowotnej, ale przede wszystkim promocję szeroko rozumianego zdrowego stylu życia, będącego wynikiem przemyślanej strategii działań profilaktycznych w zakresie funkcjonowania człowieka. Rozbudzanie zamiłowania do świata przyrody poprzez ukazywanie jego bogactwa i możliwości pozytywnego oddziaływania na życie ludzkie realizowane jest właściwie od początków procesu wychowania przedszkolnego, jak i zawarte jest $\mathrm{w}$ treściach edukacji szkolnej. Mam tu jednak na myśli nade wszystko lansowanie świadomości znaczenia świata roślin i zwierząt dla zdrowia człowieka, a co za tym idzie promowanie postaw chroniących przyrodę oraz wskazywanie, jak istotna jest, szczególnie dla człowieka współczesnego, dbałość o nią. Zważmy, iż jest to jeden z istotnych elementów życia ludzkiego wpływających na przywrócenie zaburzonej w obecnych czasach harmonii skiego.

* Dr Agnieszka Sojka - adiunkt w Instytucie Pedagogiki Uniwersytetu Jagielloń- 
i ładu wewnętrznego (psychicznego) oraz tak zwanych procesów homeostazy właściwych dla prawidłowo funkcjonującego organizmu ludzkiego.

Obok przekazów współczesnej kultury, mających udział w kształtowaniu gustów i upodobań, takich jak wszechobecne media, poszukujemy źródeł mogących ujawniać obraz przyrody, a tym samym potencjalnie formować człowieka ku wartościom witalnym, wśród których najistotniejszą jest życie samo w sobie, ale również ku osobowym oraz moralnym wyrażającym się w konkretnych postawach wobec życia ludzkiego oraz świata przyrody. Jednym z przekazów, istotnym w procesie socjalizacji, jest muzyka, a w jej obrębie formy wokalne (wokalno-instrumentalne), ze względu na zawarty w nich przekaz słowny odzwierciedlający konkretne wartości przekładające się na realne sytuacje, wyrażane poprzez decyzje, wybory, działania w codziennym życiu współczesnych pokoleń.

Przedmiotem niniejszego artykułu jest obraz przyrody w pieśni religijnej ${ }^{1}$. Celem jest ogląd problematyki ekologicznej, występującej w źródłach myśli chrześcijańskiej, w tym wypadku w pieśniach, a tym samym ujawnienie obrazu kreowanego w tekstach literackich gatunku muzycznego, jakim jest pieśń o tematyce religijnej. Przez obraz przyrody rozumiem wykreowany przez twórcę tekstu pieśni religijnej wizerunek wszechświata. Do analizy wybrałam zarówno teksty pieśni dawnych, jak współcześnie powstających piosenek religijnych. Repertuar pieśniowy zaczerpnęłam ze śpiewników diecezjalnych bądź parafialnych ${ }^{2}$. Wśród zebranego materiału znajdują się

${ }^{1}$ Wyniki badań nad fenomenem polskiej pieśni religijnej zawarłam w szeregu artykułów publikowanych m.in. na łamach Paedagogia Christiana oraz w książce mojego autorstwa Człowiek i Bóg w pieśni. Studium antropologiczno-pedagogiczne, Kraków 2008.

${ }^{2}$ Do opracowania tekstu posłużyły następujące śpiewniki: H. Chamski (oprac.), AbbaOjcze. Pieśni i piosenki religijne, Olsztyn-Płock 1996; R. Pleszka (red.), A ten który sercem Pana swego zna... Śpiewnik Wspólnoty Odnowy w Duchu Świętym, Racibórz 1999; Bóg dobry jest. Śpiewnik dla dzieci, Warszawa 1986; M. Biniorz, P. Jarosz, Z. Parkita (red.), Bóg jest mitością. Śpiewnik, Kielce 1999; Cantate Domino, Warszawa-Gorzów 1977; M. Machura (red.), Ciebie Boże chwalimy, Kraków; Exsultate Deo. Śpiewnik mszalny, bm 1990; Fioretti, Kraków 1991; Magnificat, brmw; Nowe Przymierze. Dodatek do śpiewnika Wspólnoty Krwi Chrystusa'94, Częstochowa 1995; A. Sionek, E. Maier, K. Miturska (oprac.), Pieśni chwaty, Lublin 1991; Przyjdź Duchu Święty. Śpiewnik Grup Odnowy w Duchu Świętym, Warszawa 1996; S. Sołtyszewski, Śpiewnik kościelny dla wszystkich, Warszawa 1957; P. Lisowski (wyb.), Śpiewajmy Panu. Śpiewnik pieśni i piosenek religijnych, Łódź 1995; A. K. Kostoń (zeb.), Śpiewamy z Papieżem. Śpiewnik młodzieży diecezji katowickiej na VI Światowy Dzień Młodzieży 14-15 sierpień 1991 Częstochowa, Katowice 1991; Śpiewnik, bmw. 1985; A. Reginek (oprac.), Śpiewnik archidiecezji katowickiej, Katowice 2000; Śpiewnik chrześcijański. Jezus żyje!, Toruń 1997; Śpiewnik dziecka bożego, Katowice 1992; E. Bąk, A. Borkowski, W. Rubin (oprac.), Śpiewnik ewangelizacyjny, Wrocław 1991; A. Bączkowski (red.), Śpiewnik Katolickiego Stowarzyszenia Młodzieży, Pelplin 2000; J. Siedlecki (oprac.), Śpiewnik kościelny, Kraków 1994; H. Chamski (oprac.), Śpiewnik kościelny Diecezji Płockiej 83, Płock 1983; 
utwory o walorach artystycznych, jak i popularne piosenki związane z funkcją użytkową, których autorstwo jest nieznane. Można wyróżnić zarówno pieśni liturgiczne przeznaczone do śpiewania w kościele podczas sprawowania obrzędów, jak i poza nim na różnego rodzaju spotkaniach na przykład modlitewnych.

Przyroda oznacza rzeczywistość materialną obejmującą zjawiska świata fizycznego nieożywionego oraz życia samego w sobie, bez szczególnego uwzględniania produktów ludzkiej działalności.

Pieśń jako utwór wokalny pisany do tekstów lirycznych jest najpowszechniejszą formą muzyczną ze wszystkich pojawiających się od starożytności do czasów współczesnych. Co istotne dla problematyki niniejszego artykułu, powstała z pieśni obrzędowych starożytnych i rodzimych ludowych, a rozwinęła się jeszcze w okresie przedpiśmiennym. W antycznej literaturze związana była z obrzędami i nosiła nazwę oda. Fenomen jej polega na zespoleniu dwóch elementów w jedną całość; słowa pisanego, drukowanego (wiersz) i zapisu nutowego (melodia). Przywiązywano do jej oddziaływania dużą wagę, jako że pełniła funkcję integracyjną oraz identyfikacyjną. Tekst literacki badanych pieśni religijnych zawiera ogólną wiedzę o świecie w interpretacji teologicznej. Jego treści mają charakter filozoficzny i światopoglądowy. Można stwierdzić, iż przedmiot badanych utworów literackomuzycznych ma implikacje filozoficzne w znaczeniu refleksji o człowieku oraz wartościach. Z łatwością można uchwycić prostotę owych tekstów oraz wyrazistość, z jaką przemawiają do adresata. Posługują się jednoznacznością w konstruowaniu wypowiedzi, jasnością przedstawienia myśli przewodniej - tematyki pieśni. Zabieg ten ułatwia odbiór utworu, jego zrozumienie, a tym samym wspomaga możliwości oddziaływania wychowawczego treści.

W analizowanych pieśniach można dostrzec przyrodę ożywioną, wyrażającą się poprzez istoty ludzkie, rośliny, planety, zwierzęta, ale również nieożywioną, do której zaliczamy między innymi: powietrze, skały, wodę, wiatr, światło słoneczne. Zwraca uwagę fakt, że nie jest ona pokazywana w tekstach sama dla siebie, ale jest metaforą czegoś innego i odsyła czytel-

Śpiewnik młodzieżowy, Warszawa 1985; Śpiewnik młodzieżowy, oprac. Zespół animatorów muzycznych Ruchu Światło-Życie oraz R. Litwińczuk, Gorzów Wielkopolski 1992; M Żuk (oprac.) Śpiewnik nowych pieśni kościelnych i piosenek religijnych, Olsztyn 1986; Śpiewnik pielgrzymkowy. Pójdę do nieba piechota, Ząbki brw.; Śpiewnik. Pieśni do Tajemnicy Przemienienia Pańskiego, Kraków 1993; I Pawlata (red.), Śpiewnik pierwszokomunijny, Łódź 1994; Śpiewnik, Ruch Rodzin Nazaretańskich, Warszawa 1993; Śpiewnik. Światowy Dzień Młodzieży, Częstochowa 1991; Śpiewnik. Święto młodzieży 20-25 lipca, Góra Św. Anny 1998; Śpiewnik. Tydzień Ewangelizacyjny Dzięgielów'99, Dzięgielów 2000; Święty Boga Kapłanie. Wiersze i pieśni o Świętym Stanistawie, Kraków 1998; R. Parol (oprac.), Święty Maksymilian w pieśni, Niepokalanów 1982; W Duchu i w Prawdzie, Kraków 1993; R. Łuc, J. Rawski (oprac.), Z całego serca i z całej duszy, 1995; S. Ziemiański, Bóg jest miłościa, Kraków1994. 
nika do rzeczywistości nadprzyrodzonej. Przyroda opisywana w pieśniach religijnych wyraża ludzkie przeżycia względem Boga-Stwórcy, a zarazem odzwierciedla porządek istniejący w naturze, regulowany kalendarzem ustanowionych corocznych świąt religijnych.

Zatem kreowany w repertuarze pieśniowym świat wartości wyłania się poprzez użycie środków artystycznego wyrazu a interesujące nas wartości witalne, moralne i osobowe oraz poznawcze, ujawniające się poprzez teksty, mogą nie być od razu uchwytne dla czytelnika. Zastanowić się można nad pięknem przyrody, które pojawia się w pieśni religijnej, a właściwie nad koncepcją piękna przejawiającego się przez wirtualnego odbiorcę utworów. Można stwierdzić na podstawie analizy, że wartość piękna jest spleciona $\mathrm{z}$ inną wartością, a mianowicie z religijną wartością, jaką jest świętość. Tym samym przejawiać się ona będzie w człowieku i w świecie poprzez Boga, jako Jego odblask. Przywodzi to na myśl romantyczną koncepcję poety i poezji, mających moc kreatorską uczestniczenia $\mathrm{w}$ akcie stwarzania jako współtworzenia rzeczywistości, właśnie świata przyrody, oraz uwieńczenia go aktem stworzenia człowieka. Piękno przyrody przejawia się w świecie przedstawionym utworów pieśniowych, szczególnie w zachwycie nad stworzeniem świata i człowieka, znajdując swój wyraz w pieśniach uwielbienia i dziękczynnych. Określenia przyrody w pieśniach chwały wielbiących Boga to między innymi: „niebo, ziemia, świat, morze, słońce, księżyc”.

Zaznaczyć należy, iż wartość piękna wyrażona jest artystycznymi środkami prostoty. Istotne jest także uchwycenie zabiegu posługiwania się wartością piękna w tekstach piosenek tworzonych dla dzieci. Polega ono na budowaniu obrazów poetyckich za pomocą słabych wartości estetycznych, czyli ładności, prostoty oraz drugorzędnych, takich jak na przykład wdzięk ${ }^{3}$.

Najbardziej znane pieśni religijne, zawierające literackie opisy przyrody, to przede wszystkim pieśni o tematyce maryjnej oraz religijne piosenki dziecięce. Wśród tytułów wyróżnić można maryjną pieśn Chwalcie łąki umajone, tak charakterystyczną dla majowych nabożeństw, a ujawniającą tętniącą życiem wiosenną przyrodę, oraz Kiedy ranne wstają zorze, używaną częstokroć jako pieśń intonowaną na wejście w porannych mszach świętych lub jako hymn jednej z modlitw brewiarzowych - jutrzni. W obu przypadkach tekst konotuje budzący się nowy dzień i wdzięczność za kolejne chwile życia jako Bożego daru.

Zauważmy, że w analizowanych pieśniach metafory przyrody używane są jako zwroty do Jezusa i Matki Bożej, ale także do trzeciej Osoby Bo-

3 Zestawienie wymienionych grup wartości, jakości oraz kategorii omawia M. Gołaszewska w pracy O naturze wartości estetycznych na tle sytuacji aksjologicznej, Kraków 1978. Ładność uważa ona za odrębną wartość, a nie jak niektórzy za słabszą postać piękna. 
skiej - Ducha Świętego. Dziecię Jezus w kolędzie pod tytułem Gdy śliczna Panna jest nazwane „wonnym kwiateczkiem”, a w piosenkach dla dzieci „polne kwiaty”, „robaczki” i inne stworzenia świata przyrody zapoznają i wprowadzają w rzeczywistość nadprzyrodzoną. Maryja porównywana jest między innymi do: wiosny (pieśń Była cicha i piękna jak wiosna), gwiazdy (pieśń Gwiazdo śliczna), lilii (pieśń Zdrowaś badź Maryja). Liczne obrazy przyrody stosowane do opisania Osoby Matki Bożej występują w Godzinkach, gdzie Pani Świata jest „gwiazdą zaranną”, „tęczą”, „ogrodem”, „palmą" i „,cedrem”, „ziemią”, „lilią miedzy cierniem”, „światłem”, „zorzą” i „księżycem”", ale i w innych pieśniach oraz piosenkach maryjnych:

[...] idzie polami

jak słońce złocista, jak biel przeczysta

$\mathrm{w}$ ciemnościach nocy $[\ldots]$

Gwiazdo śliczna wspaniała /pieśń Zbliża się do nas/

Tyś gwiazdą przewodnią,

$[\ldots]$

O piękna Dolino, rozkwitła liliami,

źródło wszelkiej łaski,

pomoc daj znękanym /pieśń Maryjo, Mitosierna Pani/

I jak przyroda może dać siły, napełnić radością, oderwać od trudności i zdystansować do nich, tak Osoba Matki Bożej - porównywana najczęściej do symboli przyrody - jest tą, która może pomóc, przyjść z radą i pocieszeniem jako pośredniczka między swoim Synem a zarazem Bogiem oraz dziećmi tu na ziemi. Stąd tak głęboka jest symbolika użytych opisów.

Najczęściej stosowane określenia, zaczerpnięte ze świata szeroko rozumianej przyrody, używane są w wezwaniach chociażby do Ducha Świętego:

Duchu Ogniu, Duchu Żarze,

Duchu Światłu, Duchu Blasku,

Duchu Wichrze i Pożarze /pieśn Duchu Ogniul

Świat przyrody jest częstym wątkiem tematycznym utworów pieśniowych przeznaczonych dla dzieci. Zjawiska natury, zwierzęta, rośliny występują jako nosiciele wartości. Posłużyć się można przykładem jednej z pio-

${ }^{4}$ Zob. A. Tronina, Zawitaj Pani Świata. Obrazy i symbole biblijne w Godzinkach, Niepokalanów 1995. 
senek religijnych dla dzieci, autorstwa ks. Stanisława Ziemiańskiego SJ, do której melodię skomponowała s. Laureta Gałuszka:

Opada cicho ranna rosa, wyjrzało słońce, wstaje świt.

Skowronek wzbił się pod niebiosa, porannym śpiewem Boga czci /piosenka Opada cicho ranna rosa/5.

Zacytowany powyżej fragment wskazuje na wartości witalne jako rudymenty wprowadzania dziecka w świat wartości wyższych, takich jak: osobowe, moralne czy religijne.

Istotnym symbolem przyrody używanym $w$ tekstach pieśni religijnych jest Życie pisane z dużej litery i utożsamiane z Bogiem.

\section{[...] Ty jesteś [...] Życiem /pieśń $W$ Tobie nadzieja mojal}

Życie samo w sobie oznacza szczęście, a Bóg jako Stwórca wszechświata jest Panem życia i śmierci, ale również jego źródłem. Określenia typu: „ogień”, „żar”, „,́́wiatło”, „,blask”, czy zestawienia takie jak: „ogień życia”, światła blask", ,gwiazda nadziei”, wskazują na postaci boskie i ich bardzo konkretne, realne, a zarazem cudowne działanie w życiu człowieka. Wymienione epitety nie tyle nawet przysługują Bogu, ile są uosobieniem Jego samego. Mówi się w tym wypadku nie o miłości w potocznym rozumieniu tego słowa, nie o dobru, które stało się udziałem człowieka, ale zaznaczone jest wyraźnie, że Źródłem i Dawcą ich jest Bóg. Są to cechy, których doświadcza zwykły człowiek:

Twym Słowem Życia nakarm mnie,

$[\ldots]$

Jedyne Życie, które trwa /pieśń $W$ Tobie nadzieja moja/ ${ }^{6}$.

Poprzez życie objawia się siła, moc i potęga Boga. Człowiek żyjąc jest w nieustannej potencjalności spełniania się, stąd też zakończenie życia ma konotacje negatywne. Życie oznacza rozwój oraz radość jako wartości oznaczające w swej treści dużo więcej niż zwykłe zadowolenie ze zdobywania dóbr ziemskich w procesie korzystania między innymi ze świata przyrody.

${ }^{5}$ S. Ziemiański, Bóg jest Miłościa, Kraków 1994.

${ }^{6}$ Cytowane pieśni pochodzą ze zbiorów własnych Zgromadzenia Sióstr Uczennic Boskiego Mistrza w Częstochowie, a także ze śpiewników podanych w przypisie 3 niniejszego artykułu. 
Obraz przyrody w pieśniach religijnych ujawnia się również dla opisania rzeczywistości obiecanej wierzącym w Chrystusa i spełniającym uczynki miłosierdzia - Królestwa Bożego. Analizy tekstów repertuaru pieśniowego wykazały posługiwanie się jeszcze innym środkiem artystycznego wyrazu, jakim jest przeciwstawienie dla mocniejszego zaznaczenia istoty prawd wiary:

W królestwie Twoim miłość włada,

Trwa wieczny pokój pośród burz,

W nim boska czeka nas biesiada /pieśń O Chryste Królu, Władco świata/7.

poślij i mnie na żniwo swe

[...]

Chcę dobroć siać, chcę miłość dać /pieśń Jeżeli chcesz/

Zauważmy, że rekwizyty przyrody są wykorzystane jako wzmacniające użyty przez twórcę tekstu literacki środek wyrazu.

Ciekawym zabiegiem stosowanym przez autorów tekstów pieśni jest stosowanie literackiego jej opisu do przekazania sytuacji podmiotu lirycznego, a tym samym ukazywanie kondycji współczesnego człowieka.

Jak deszcz dotykiem swoich łez

na świat strumienie życia śle /pieśń Uwielbienie/

od konarów wzruszeń wrażliwości słów /pieśń Matko wracajacych/

gwiazdy świecą, słońce też

i na ziemię pada deszcz

[...]

pachnie niebem

Często chodzę jak we mgle /pieśń Jestem coraz blizej Ciebiel

Tak jak rosa na wyschłą ziemię naszych serc

- przybądź [...]

Tak jak światło co rozjaśnia ślepca mrok /pieśń Mistrzu przyjdźl

Mocą Twą płonie blask dalekich gwiazd,

Stulony pąk przemieniasz w polny kwiat /pieśń Komunia/

7 Tamże. 
W badanych pieśniach kreowany obraz przyrody współtworzy wizerunek świata jako pewnej komunikującej się ze sobą, złożonej rzeczywistości. Bohaterem lirycznym jest człowiek grzeszny, szukający sensu życia, prawdy, ratunku, ocalenia. Istota ludzka narażona jest na niespójność i przypadkowość świata, a tym samym poczucie zagubienia w nim i pragnienie zamieszkania go oraz poznania i opanowania go. Ujawnia się chęć władania światem przyrody, która w skrajnej wersji może doprowadzić do podporządkowania go sobie bez uznania naturalnych granic wyznaczonych przez prawa przyrody, a tym samym doprowadzenie do katastrof, których jesteśmy świadkami w czasach obecnych. Granica między sensem istnienia a bezsensem nieistnienia wyznaczona zostaje również poprzez umiejętne posługiwanie się obrazem przyrody.

Charakterystyczne dla sposobu przedstawiania obrazu przyrody są proste określenia, którymi operują autorzy tekstów pieśni religijnych, takie jak:

Nowe niech będą niebo i ziemia. /pieśń Bóg jest Miłością /

Patrzę na ptaki i lilie polne,

Widzę, jak Ojcze troszczysz się o nie;

$[\ldots]$

Dzielmy się chlebem, dzielmy się niebem /pieśń Patrzę na ptaki/

Z Ciebie wypływa rzeka

z Ciebie wybucha ogień

$[\ldots]$

W Tobie głębia jest bez dna, wysokość

bez kresu, szerokość bez miary

i czystość $[\ldots]$

W Tobie jest źródło życia

Biegnę do tego źródła

Najczystszej jasności światła,

Do życia co ożywia me życie/pieśń Źródlo życial

Zrozumiałe są również rekwizyty, którymi posługują się kolędy polskie, wśród których wyróżnić można przede wszystkim elementy świata przyrody, jakimi są zwierzęta i rośliny, ale także inne nawiązujące do niego na przykład: siano, żłóbek, szopa, stajenka.

${ }^{8}$ Pieśń w formie apelu skomponowana na VII pielgrzymkę Jana Pawła II do Polski; nie mylić z pieśnią przygodną pod tym samym tytułem. 
Powyższe przykłady pieśni ukazują funkcję literackiego opisu przyrody, który służy oddaniu prawdy religijnej - prawdy wiary, ale przekazuje też wiedzę o świecie. Istotna jest jego rola jako tła dla ukazania szerszej perspektywy życia ludzkiego zarówno w wymiarze horyzontalnym w relacji do drugiego człowieka, ale poszerzonego o wertykalne odniesienie do Boga. Omawiane funkcje jeszcze mocniej wybrzmiewają w dawnych pieśniach na przykład adwentowych:

Spuście łaskawe niebiosa,

Spuście z deszczem obłoki!

Niechaj zstąpi jako rosa [...]

Niech nam ziemia tego zrodzi [...]

Skrusz niebieskie sklepienie /pieśń Spuście nam na ziemskie niwy/

Podobnie w kolędzie Bóg się rodzi do tekstu M. Karpińskiego, gdzie mamy do czynienia ze wspomnianym już środkiem artystycznego wyrazu, jakim jest oksymoron: „Ogień krzepnie, blask ciemnieje” lub w pieśni wielkopostnej Jezu Chryste, Panie Miły również operującej przeciwstawieniami na przykład: „słońce światłość swą zawiera”, ,ziemia się rwie, łamie skała”.

Warto uświadomić sobie, że obraz przyrody towarzyszy także opisowi krzyża, tak istotnemu znakowi w religii chrześcijańskiej, na którym dokonał życia ziemskiego Chrystus:

Krzyżu Święty, nade wszystko,

Drzewo przenajszlachetniejsze.

W żadnym lesie takie nie jest,

$[\ldots]$

Słodkie drzewo, $[\ldots]$

Rozkoszny owoc nosiło.

Skłoń gałązki, [...] /pieśń Krzyżu Święty, nade wszystko/

Wartości takie jak: jasność, światłość, ład, spokój, piękno, używane często w pieśniach religijnych a wskazujące na świat przyrody zharmonizowany odzwierciedlają ogólnoludzką potrzebę do porządkowania przestrzeni wokół i dążność do utrzymywania homeostazy poprzez właściwe odniesienie się człowieka do świata przyrodniczego zarówno roślinnego, jak i zwierzęcego. Uwidacznia się tutaj jedność między światem ludzkim i zwierzęco-roślinnym.

Świat wartości witalnych opisany w tekstach pieśni jest światem jakościowym i sposób jego opisu charakteryzuje się użyciem środków artystycznego wyrazu. $\mathrm{Z}$ jednej strony umożliwia to odbiorcy obcowanie 
z wartościami poprzez przeżycie estetyczne w kontakcie z dziełem literacko-muzycznym ${ }^{9}$, ale również zachęca do osobistego czerpania korzyści duchowych i materialnych ze świata przyrody poprzez indywidualną kontemplację natury.

Pieśń może być uważana za komunikat służący przekazywaniu treści wychowawczych. Istotny przy tym jest fakt, że niekoniecznie występować muszą one w sposób dosłowny w tekstach, ale mogą zostać z nich wyinterpretowane, co uczyniono w niniejszym tekście.

Wyzwalając zarówno w nadawcy, jak i odbiorcy radość życia, pozwalają na odkrycie sensu, a tym samym jego wartości. Realizacja duchowego wymiaru człowieka, będąca przesłaniem polskich pieśni religijnych, odbywa się również w trakcie uczestniczenia w kulturze. Teksty poetyckie ewokują wartości dotyczące zarówno ducha, psychiki, jak i ciała ludzkiego, implikując integralną, holistyczną wizję człowieka w procesie nieustannego jego rozwoju - stawania się.

Polska pieśń religijna w perspektywie prowadzonych przez autorkę niniejszego artykułu badań fenomenologicznych jawi się jako środek wyzwalający przeżycie wartości zawartych w warstwie tekstowej, o które chodzi w procesie wychowania. Element muzyczny jest dodatkowym bodźcem stymulującym owo przeżycie. Jak zaznacza Maria Przychodzińska: ,[...] tekst poetycki wywołuje przeżycia swoiste w swej naturze, pobudzane semantyką i poetyką słowa, gdy jednak zjawia się towarzysząca mu muzyka, przeżycie poetyckie zmienia charakter, staje się silniej lub inaczej emocjonalne; warstwa muzyczna uintensywnia je, choć sama pozostaje w tle, ujmowana często podświadomie" 10 . W taki sposób zdefiniowana pieśń koresponduje z myślą Johanna Georga Sulzera, który stwierdził, iż zadaniem pieśni jest „,poprzez prostą i krótką melodię znaleźć prostą drogę do serca”, gdyż „nie chodzi tu o uciechę dla uszu, ani o zadziwienie sztuką, czy o zaskoczenie przez kunsztowne harmonie i ociężałe modulacje - lecz jedynie o wzruszenie"11.

Poznawanie świata przyrody wraz z wnikaniem w jego harmonię jest znaczące szczególnie dla ludzi żyjących w szybko rozwijających się cywilizacjach. Nabyte doświadczenia w tym zakresie mogą stanowić środek nie tylko umożliwiający człowiekowi kontakt ze Stwórcą, ale również będący panaceum na alienację, lecząc i przywracając kontakt z samym sobą.

9 Zob. R. Ingarden, Przė̇ycie estetyczne i przedmiot estetyczny, w: tenże, O poznawaniu dzieła literackiego, Warszawa 1976.

${ }^{10}$ M. Przychodzińska, Wychowanie muzyczne-idee, treści, kierunki rozwoju, Warszawa 1989, s. 96.

${ }^{11}$ Cyt. za: Allgemeine Theorie der Schönen Künste, Leipzig 1771-1774, hasło Lied. M. Tomaszewski, Od wyznania do wołania. Studia nad pieśnią romantyczną, Kraków 1997, s. 62-63. 


\section{Nature Symbolism in Religious Music (Summary)}

The objective of the research is to show that the use of nature imagery is a very important aspect in religious songs. These images and symbols such as valleys, mountains, and flowers are used to describe the holy figures including Jesus, Mary, Joseph, God the Father, and the Holy Spirit. The analysis of lyrics in a variety of Polish religious songs proves that nature is an important and underlying theme in these texts. 